\title{
ANALISIS KINERJA KEUANGAN \\ PT. BANK NEGARA INDONESIA (Persero) Tbk. \\ TAHUN 2019-2020
}

Oleh :

\author{
Hilman Suryawan Saharuddin \\ Institut Bisnis dan Keuangan Nitro Makassar \\ Email : himan.suryawan310100@gmail.com
}

\begin{abstract}
ABSTRAK
Dalam dunia perbankan, keuangan sangat berpengaruh terhadap kelangsungan kegiatan suatu perbankan serta setiap individu dalam perbankan itu. Dalam suatu perusahaan juga diperlukan suatu analisis laporan keuangan untuk mengetahui kemampuan perusahaan dalam mengatasi masalah keuangan perusahaan serta pengambilan keputusan yang cepat dan tepat. Rumusan masalah dalam penelitian ini adalah bagaimana kinerja keuangan pada PT. Bank Negara Indonesia (Persero) Tbk. tahun 2019-2020. Tujuan penelitian adalah untuk mengetahui kinerja keuangan pada PT. Bank Negara Indonesia (Persero) Tbk. tahun 2019-2020. Teknik analisis data yang digunakan dalam penelitian ini dengan menggunakan rasio keuangan bank. Berdasarkan hasil penelitian rasio keuangan korporasi bank masih mengalami fluktuasi. Penilaian Likuiditas PT. Bank Negara Indonesia (Persero) Tbk. Masih mampu membayar kewajiban keuangannya. Penilaian Solvabilitas Bank memiliki permodalan yang memadai. Penilaian terhadap profitabilitas perusahaan masih mengalami peningkatan laba.
\end{abstract}

Kata Kunci : Laporan Kinerja Keuangan, Rasio Keuangan 


\section{PENDAHULUAN}

Secara garis besar lembaga keuangan dapat dibedakan menjadi dua yaitu lembaga keuangan bank dan lembaga keuangan non bank. Lembaga keungan Bank merupakan lembaga yang berfungsi sebagai penghimpun dana dari masyarakat dalam bentuk simpanan dan menyalurkannya kembali kepada masyarakat dalam bentuk kredit. Fungsi bank yang seperti ini disebut sebagai fungsi intermediasi, jika proses intermediasi berjalan dengan baik maka semua pihak baik bank, pihak yang kelebihan dana, pihak yang kekurangan dana dan pada gilirannya perekonomian secara keseluruhan akan memperoleh manfaat dari keberadaan suatu bank. Falsafah yang mendasari kegiatan usaha bank adalah kepercayaan masyarakat, sebagai lembaga kepercayaan dalam operasionalnya bank lebih banyak menggunakan dana masyarakat dibandingkan dana dari pemilik modal atau pemegang saham sehingga bank perlu memelihara kinerja usaha dan tingkat kesehatannya.

Bank Indonesia selaku bank sentral mempunyai peranan yang penting dalam penyehatan perbankan, karena Bank Indonesia bertugas mengatur dan mengawasi jalannya kegiatan operasional Bank. Berdasarkan peraturan Bank Indonesia Nomor 6/10/PBI/2004 tentang sistem penilaian Tingkat kesehatan Bank Umum, tingkat kesehatan bank dapat dinilai dari beberapa indikator.Salah satunya sumber utama indikator yang dijadikan dasar penilaian adalah laporan keuangan bank yang bersangkutan.

Kinerja keuangan adalah prestasi yang dapat dicapai oleh perusahaan dibidang keuangan dalam suatu periode tertentu yang mencerminkan tingkat 
kesehatan perusahaan (Soemarso, 2014:380). Sedangkan menurut Fahmi (2017:2) kinerja keuangan merupakan suatu analisis yang dilakukan guna mengetahui sejauh mana perusahaan sudah melaksanakan aturan yang sudah ditetapkan terkait dengan penggunaan keuangan secara tepat dengan benar. Seperti dengan membuat suatu laporan yang telah memenuhi standar dan ketentuan dalam SAK (Standar Akuntansi Manajemen). Dengan kata lain kinerja keuangan berkaitan erat dengan kemampuan manajemen dalam mengelola sumber daya yang dimiliki perusahaan secara efektif dan efisien untuk mencapai profit.

Gambaran mengenai kinerja keuangan perusahaan dapat dilihat melalui laporan keuangan yang diterbitkan oleh perusahaan. Laporan keuangan diharapkan akan membantu para pengguna eksternal untuk membuat keputusan ekonomi yang bersifat finansial.

PT. Bank Negara Indonesia (Persero) Tbk. merupakan bank umum pertama yang didirikan dan dimiliki oleh Pemerintah Indonesia, yaitu sejak tahun 1946. Sejalan dengan keputusan penggunaan tahun pendirian sebagai bagian dari identitas perusahaan, nama BNI 1946 resmi digunakan mulai akhir tahun1968. Perubahan ini menjadikan BNI lebih dikenal sebagai BNI 46. Pada tahun 1992, status hukum dan nama BNI berubah menjadi PT BNI (Persero). Keputusan untuk menjadi perusahaan publik diwujudkan melalui penawaran saham perdana di pasar modal pada tahun 2000. Kemampuan BNI untuk beradaptasi terhadap perubahan dan kemajuan lingkungan, sosial budaya serta teknologi dicerminkan melalui penyempurnaan identitas perusahaan yang 
berkelanjutan dari masa ke masa. Hal ini juga menegaskan dedikasi dan komitmen BNI terhadap perbaikan kualitas kinerja secara terus menerus.

Perkembangan dan persaingan industri perbankan yang semakin ketat mengharuskan setiap bank untuk memiliki strategi yang tepat dalam mencapai keunggulan bersaing. Dalam hal ini, PT. Bank Negara Indonesia (Persero) Tbk. harus mampu mengembangkan perusahaannya. Salah satunya dengan cara memiliki strategi yang baik dan unggul melalui perencanaan strategi. Untuk membuat sebuah perencanaan strategi yang baik, diperlukan alat manajemen strategi yang mampu secara komprensif melihat perspektif yang ada dalam suatu perusahaan.

Untuk mengetahui seberapa baik keuntungan dan kinerja keuangan suatu perusahaan dapat dilihat dari laporan keuangan perusahaan tersebut, karena pada laporan keuangan tertuang segala aktivitas dan transaksi yang dilakukan oleh perusahaan. Menurut Rodoni dan Ali (2014:13) Laporan keuangan adalah sebuah laporan keuangan yang diterbitkan oleh perusahaan untuk para pemegang sahamnya. Laporan memuat laporan keuangan dasar dan juga analisis manajemen dan juga operasi tahun lalu dan pendapat mengenai prospek-prospek perusahaan dimasa mendatang.

Keadaan keuangan PT. Bank Negara Indonesia (Persero) Tbk. Sebagai berikut yang tertera dibawah. 
Tabel 1

Ringkasan Laporan Keuangan PT Bank Negara Indonesia (Persero)

Tbk.

Tahun $2019-2020$

(dalam miliar rupiah)

\begin{tabular}{|l|c|c|c|}
\hline \multicolumn{1}{|c|}{ KETERANGAN } & $\mathbf{2 0 1 9}$ & $\mathbf{2 0 2 0}$ & \multicolumn{1}{c|}{$\%$} \\
\hline Aktiva & 845,605 & 891,337 & 5,41 \\
\hline Hutang & 720,601 & 746,236 & 3,56 \\
\hline Ekuitas & 125,004 & 112,872 & $-9,71$ \\
\hline Laba sebelum PPH & 19,369 & 5,112 & 73,61 \\
\hline
\end{tabular}

Sumber : Laporan Keuangan BNI tahun 2020

PT. Bank Negara Indonesia (Persero) Tbk. pada tahun 2020, mengalami kenaikan aktiva sebesar 5,41\% kenaikan hutang sebesar 3,56\% ekuitas menurun 9,71\%. Laba sebelum PPH Badan turun sebesar 73,61\% perbandingan tahun 2019. Tahun 2019 PT. Bank Negara Indonesia memperoleh laba sebesar Rp. 19.369.000.000,- dan tahun 2020 memperoleh laba sebesar Rp. 5.112.000.000,-

Penyebab terjadinya penurunan yang mengakibatkan tidak maksimalnya pencapaian laba salah satunya adalah meningkatnya kasus Covid 19 di 
Indonesia. Dampak pandemi Covid 19 yang terjadi di Indonesia adalah meningkatnya kredit macet.

Maka dari fenomena ini pentingnya dilakukan evaluasi kinerja suatu perusahaan agar dapat kembali berjalan secara maksimal demi kelangsungan hidup perusahaan di masa pandemi ini. Berdasarkan hal tersebut di atas, penulis tertarik untuk mengambil judul penelitian "Analisis Kinerja Keuangan Pada PT Bank Negara Indonesia (Persero) Tbk. Tahun 2019-2020”.

\section{TINJAUAN PUSTAKA}

\section{A. LANDASAN TEORI}

\section{Laporan Keuangan}

Menurut Kasmir (2014:2) laporan keuangan pada dasarnya adalah hasil proses akuntansi yang dapat digunakan sebagai alat untuk berkomunikasi antara data keuangan dan aktivitas suatu perusahaan dengan pihak-pihak yang berkepentingan dengan data dan aktivitas dari perusahaan tersebut. Dengan kata lain, laporan keuangan ini sebagai alat yang menghubungkan perusahaan dengan pihak-pihak yang berkepentingan terhadap perusahaan.

Kasmir (2014:2) mendefinisikan laporan keuangan adalahlaporan yang menunjukkan kondisi keuangan perusahaan pada saat ini atau dalam satu periode tertentu. Laporan keuangan merupakan suatu informasi yang menggambarkan kondisi keuangan suatu perusahaan, dan informasi tersebut dapat dijadikan sebagai gambaran kinerja keuangan perusahaan tersebut. Hery (2020:3) 
berpendapatan bahwa laporan keuangan merupakan produk akhir serangkaian pencatatan dan pengikhtisaran data transaksi bisnis.

Berdasarkan definisi diatas, dapat disimpulkan bahwa laporan keuangan adalah laporan yang menyajikan infomasi mengenai keuangan perusahaan yang dapat digunakan oleh pihak-pihak yang memiliki kepentingan mengenai posisi keuangan, kinerja perusahaan, perubahan ekuitas, dan merupakan hasil dari periode akuntansi dari suatu usaha.

\section{Rasio Keuangan}

Menurut Harahap (2016:297) rasio keuangan adalah angka yang popular dari hasil perbandingan dari suatu pos laporan keuangan dengan pos lainnya yang mempunyai hubungan yang relevan dan signifikan.

Hery (2020:139) berpendapat bahwa analisis rasio keuangan adalah analisis yang dilakukan dengan menghubungkan berbagai perkiraan yang ada pada laporan keuangan dalam bentuk rasio keuangan. Rasio keuangan ini dapat mengungkapkan hubungan yang penting antar perkiraan dan dapat digunakan untuk mengevaluasi kondisi keuangan dan kinerja perusahaan.

Sunyoto (2013:63) menyatakan bahwa analisis rasio keuangan adalah suatu teknik analisis untuk mengetahui hubungan pos-pos tertentu dalam neraca atau rugi laba secara individu atau kombinasi darikedua laporan tersebut.

Kinerja keuangan diukur dengan data fundamental perusahaan 
yaitu data yang berasal dari laporan keuangan dengan menggunakan rasio likuiditas, solvabilitas, aktivitas dan profitabilitas.

1. Rasio Likuiditas

Rasio ini mengukur kemampuan perusahaan untuk melunasi hutang-hutang jangka pendek yang segera jatuh tempo.

a) Rasio Lancar (Current Ratio)

Rasio yang mengukur kemampuan perusahaan memenuhi hutang jangka pendek menggunakan aktiva lancar. Dengan menggunakan rumus :

$\mathrm{CR}=\frac{\text { Aktiva Lancar }}{\text { Hutang Lancar }} \times 100 \%$

b) Rasio cepat (Quick Ratio)

Rasio yang menunjukkan kemampuan perusahaan dalam memenuhi atau membayar hutang jangka pendek dengan aktiva lancar tanpa memperhitungkan nilai persediaan. Dengan menggunakan rumus :

$\mathrm{QR}=\frac{\text { Aktiva Lancar }- \text { Persediaan }}{\text { Hutang Lancar }} \times 100 \%$

2. Rasio Solvabilitas

Rasio untuk mengukur kemampuan perusahaan memenuhi kewajiban-kewajiban jangka panjangnya.

a) Rasio Total Hutang Terhadap Aset (Debt to Asset Ratio)

Rasio untuk mengukur perbandingan antara total 
utang dengan total aktiva. Dengan menggunakan rumus

Debt Ratio $=\frac{\text { Total Hutang }}{\text { Total Aset }} \times 100 \%$

b) Rasio Utang Terhadap Ekuitas (Debt to Equity Ratio)

Rasio untuk membandingkan seluruh utang, termasuk utang lancar dengan seluruh ekuitas. Dengan menggunakan rumus:

DER $=\frac{\text { Total } \text { Hutang }}{\text { Ekuitas }} \times 100 \%$

3. Rasio Aktivitas

Rasio yang digunakan untuk mengukur tingkat efisiensiatas pemanfaatan sumber daya yang dimiliki perusahaan atau untuk menilai kemampuan perusahaan dalam menjalankan aktivitasnya sehari-hari.

a) Rasio perputaran aktiva tetap

Rasio ini digunakan untuk melihat sejauh mana perusahaan dapat menghasilkan penjualan dengan aktiva tetap yang dimiliki. Dengan menggunakan rumus

Perputaran aktiva tetap $=\frac{\text { Penjualan }}{\text { Aktiva } \text { tetap }} \times 100 \%$

b) Rasio perputaran total aktiva

Hampir sama dengan perputaran rasio aktiva tetap, hanya saja yang membedakan perhitungan kali ini adalah total aktiva yang dimiliki perusahaan. Dengan menggunakan rumus : 
Rasio total aktiva $=\frac{\text { Penjualan }}{\text { Total Aktiva }} \times 100 \%$

4. Rasio profitabilitas

Rasio yang menggambarkan kemampuan perusahaan dalam menghasilkaan laba.

a) Hasil pengembalian aset (Return On Assets Ratio)

Rasio untuk menilai persentase keuntungan (laba) yang diperoleh perusahaan. Dengan menggunakan rumus :

$\mathrm{ROA}=\frac{\text { Laba Bersih }}{\text { Total Aset }} \times 100 \%$

b) Hasil pengembalian Ekuitas (Return On Equity)

Rasio untuk mengukur laba bersih sesudah pajak dengaan modal sendiri. Dengan menggunakan rumus :

$\mathrm{ROE}=\frac{\text { Laba Bersih }}{\text { Ekuitas }} \times 100 \%$

c) Margin laba kotor (Gross Profit Margin)

Rasio untuk menilai persentase laba kotor terhadap pendapatan yang dihasilkan dari penjualan. Dengan menggunakan rumus :

$\mathrm{GPM}=\frac{\text { Laba Kotor }}{\text { Total Pendapatan }} \times 100 \%$

d) Margin Laba Bersih (Net Profit Margin)

Rasio untuk menilai persentase laba bersih yang didapat setelah dikurangi pajak terhadap pendapatan yang diperoleh dari penjualan. Dengan menggunakan rumus : 


$$
\mathrm{NPM}=\frac{\text { Laba bersih } \operatorname{seletah} \text { pajak }}{\text { Penjualan }} \times 100 \%
$$

3. Analisis Laporan Keuangan

Setelah laporan keuangan dibuat, maka akan terlihat bagaimana kondisi keuangan dari perusahaan yang sesungguhnya. Kondisi keuangan yang dimaksud yaitu, diketahuinya jumlah harta (kekayaan), modal (ekuitas), dan kewajiban (utang) dalam neraca yang dimiliki kemudian dapat diketahui juga jumlah pendapatan yang akan diterima dan biaya yang akan dikeluarkan pada periode tertentu. Dengan demikian dapat diketahui bagaimana hasil usaha (laba atau rugi) selama periode tertentu dari laporan laba rugi yang ada.

Analisis laporan keuangan pada dasarnya dilakukan karena ingin mengetahui tingkat profitabilitas (keuntungan) dan tingkat kesehatan perusahaan. Dalam menganalisis laporan keuangan biasanya dilakukan dengan cara menghitung rasio-rasio keuangan.

Dengan adanya analisis laporan keuangan, perusahaan dapat mengetahui posisi keuangan dan digunakan sebaagai tolak ukur dalam pencapaian target yang telah direncanakan sebelumnya. Laporan keuangan ini disusun dan ditafsirkan untuk kepentingan manajemen dan pihak lain yang menaruh perhatian ataumempunyai kepentingan dengan data keuangan perusahaan.

Sebelum melakukan analisis laporan keuangan, diperlukan langkah-langkah atau prosedur tertentu. Langkah atau prosedur ini diperlukan, agar urutan proses analisis mudah untuk dilakukan. 
Adapun langkah ataupun prosedur yang dilakukan dalam analisis keuangan sebaagai berikut (Hery, 2020:114) :

a. Mengumpulkan data keuangan dan data pendukung yang diperlukan selengkap mungkin, baik untuk satu periode maupun beberapa periode.

b. Melakukan pengukuran-pengukuran atau perhitunganperhitungan secara cermat dengan memasukkan angkaangka yang ada dalam laporan keuangan kedalam rumusrumus tertentu.

c. Memberikan interpretasi terhadap hasil perhitungan dan pengukuran yang telah dilakukan.

d. Membuat laporan hasil analisis

e. Memberikan rekomendasi sehubung dengan hasil analisisyang dilakukan.

\section{B. PENELITIAN TERDAHULU}

A. Wilna Feronika Rabuisa (2018) melakukan penelitian dengan judul "Analisis Laporan Keuangan Dalam Menilai Kinerja Keuangan Perusahaan Pada Bank Perkreditan Rakyat (BPR) Dana Raya Manado". Tujuan dalam penelitian yang dilakukan adalah sebagai penyedia atas informasi yang berhubungan dengan posisi, kinerja, dan perubahan posisi keuangan suatu perusahaan yang bermanfaat sebagai pengambilan keputusan ekonomi perusahaan.

B. Milke Destiana Tandilimbong (2015) melakukan penelitian dengan judul "Analisis Kinerja Keuangan pada PT. Bank Negara Indonesia 
(Persero) Tbk. Kantor Cabang Makassar". Tujuan dalam penelitian yang dilakukan adalah untuk mengetahui tingkat kesehatan pada kinerja keuangan PT. Bank Negara Indonesia (Persero) Tbk.

C. Rosnaini Daga (2017) Tujuan dari penelitian ini adalah untuk menganalisis strategi yang digunakan oleh PT. Bank Perkreditan Rakyat Hasamitra Cabang Makassar dalam meningkatkan kepuasan nasabah tabungan. Penelitian ini dilakukan di PT. Hasamitra Bank Perkreditan Cabang Makassar di Jl. Wahidin Sudirohusodo menggunakan metode deskriptif kualitatif. Hasil yang diperoleh menunjukkan bahwa strategi yang digunakan oleh PT. Bank Perkreditan Rakyat Hasamitra dalam meningkatkan kepuasan nasabah menabung merupakan strategi standar pelayanan bank. strategi pemasaran yang dilakukan telah mampu meningkatkan jumlah pelanggan, hal ini berarti strategi pemasaran yang dilakukan sudah efektif dalam meningkatkan jumlah pelanggan.

\section{KERANGKA PIKIR}

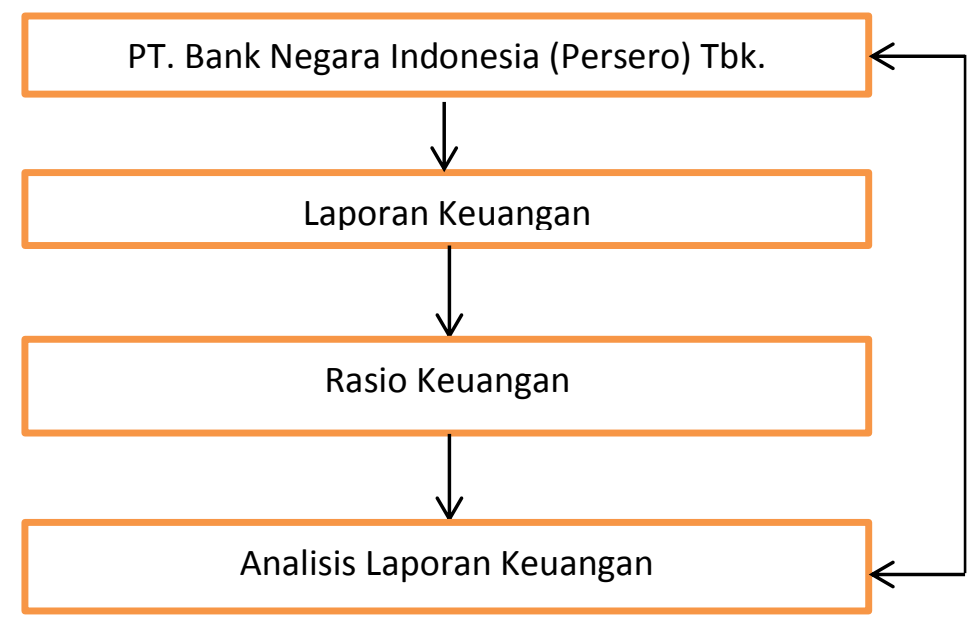


Vol. 1, Juli 2021

Keterangan :

Kerangka pikir ini merupakan penjelasan terhadap masalah yang menjadi objek dalam penelitian ini. Kerangka pikir ini dibuat untuk memberikan gambaran penelitian yang akan dilakukan yaitu mengetahui analisis kinerja keuangan dan dijelaskan bahwa dari laporan keuangan dengan menggunakan rasio keuangan yang terdiri dari empat rasio yaitu likuiditas, solvabilitas, profilitabilitas, dan aktivitas untuk mengetahui kinerja keuangan.

\section{METODE PENELITIAN}

\section{A. LOKASI DAN WAKTU PENELITIAN}

Penelitian ini dilakukan di PT. Bank Negara Indonesia (Persero). Tbk yang beralamat di Jl. A.P Pettarani, Kota Makassar. Dengan waktu penelitian selama kurang lebih (satu) bulan.

\section{B. JENIS DAN SUMBER DATA}

\section{JENIS DATA}

Jenis data yang digunakan dalam penelitian ini berupa data kuantitatif, yaitu data berupa laporan keuangan PT. Bank Negara Indonesia (Persero) Tbk. tahun 2019-2020.

\section{SUMBER DATA}

Dalam penelitian ini, data yang digunakan bersumber dari data primer berupa data keuangan yang bersifat kuntitatif dan juga 
diperoleh dari sumber pertama yang diperoleh melalui website.

\section{TEKNIK PENGUMPULAN DATA}

\section{Penelitian Kepustakaan (Library Research)}

Penelitian ini dilakukan dengan cara mendapatkan informasi yang diperoleh dengan mempelajari referansi, jurnal, buku-buku literatur yang berkaitan dengan masalah yang dibahas.

\section{Penelitian Dokumentasi}

Metode ini merupakan teknik pengumpulan data yang dilakukan dengan mencari data mengenai variable yang diteliti, yaitu dengan mengumpulkan laporan keuangan dan dokumentasi-dokumentasi yang berkaitan dengan penelitian.

\section{POPULASI DAN SAMPEL}

1. Populasi

Populasi yang digunakan dalam penelian ini adalah laporan keuangan pada PT. Bank Negara Indonesia (Persero) Tbk. Tahun 2019-2020.

2. Sampel

Sampel yang digunakan dalam peneltian ini adalah sampel jenuh, dimana semua populasi dijadikan sampel. Adapun sampel dalam penelitian ini adalah laporan keuangan pada PT. Bank Negara Indonesia (Persero) Tbk. Tahun 2019-2020.

\section{E. DEFINISI OPERASIONAL}

Kinerja keuangan merupakan gambaran kondisi keuangan 


\section{Jurnal Manajemen Keuangan}

Vol. 1, Juli 2021

perusahaan pada suatu periode tertentu baaik aspek penghimpunan dan maupun penyaluran dana yang terjadi dalam perusahaan. Kinerja keuangan PT. Bank Negara Indonesia (Persero) Tbk., didalam penelitian ini menggunakan beberapa rasio-rasio diantaranya sebagai berikut :

1. Rasio Likuiditas ini menunjukkan kemampuan PT. Bank Negara Indonesia (Persero) Tbk dalam memenuhi kewajiban atau utang jangkapendek yang diwakili:

a. Current Ratio : rasio yang dihasilkan dari perbandingan antara aktiva lancar dengan utang jangka pendek.

b. Quick Ratio : hasil perbandingan antara aktiva lancar dikurangi persediaan dengan total kewajiban jangka pendek.

2. Rasio solvabilitas menggambarkan tentang seberapa besar kebutuhan PT. Bank Negara Indonesia (Persero) Tbk. yang dibiayai oleh utang yang diwakili oleh:

a. Debt ratio : Rasio yang digunakan untuk mengukur sebesar perusahaan mengandalkan hutang untuk membiayai asetnya.

b. Times Interest Earned : Rasio yang mengukur kemampuan perusahaan dalam membayaratau menutupi beban bunga dimasa depan.

3. Rasio Aktivitas adalah rasio-rasio yang digunakan untuk menilai beberapa besar efesiensi atau efektivitas PT. Bank Negara Indonesia (Persero) Tbk. dalam pemanfaatan sumber daya atau asset yang dimilikinya, yang diwakili : 
Vol. 1, Juli 2021

a. Turn Assets Turn Over : perbandingan dimana rasio ini menggambarkan kecepatan perputaran total aktiva selama satu periode tertentu.

b. Fixed Assed Turn Over: perbandingan antara penjualan dengan aktiva tetap.

4. Rasio profitabilitas digunakan untuk mengukur kemampuaan PT. Bank Negara Indonesia (Persero) Tbk. untuk menghasilkan laba dari pendapatan yang berhubungan dengan penjualaan, aset dan ekuitas, yang diwakili :

a. Gross Profit Margin : Rasio yang membandingkan antara laba Kotor dengan penjualan atau pendapatan yang ada.

b. Return On Total Assets : rasio keuangan dalam perusahaan yang terkait dengan potensi keuntungan yang diperoleh dengan mengukur kekuatan perusahaan membuahkan keuntungan atau juga laba pada tingkat pendapatan aset dan juga modal saham spesifik.

c. Return On Equity : Perbandingan antara laba bersihsesudah pajak dengan total ekuitas.

d. Net Profit Margin : Perbandingan total jumlah laba bersih dengan total jumlah pendapatan perusahaan.

\section{F. ANALISIS DATA}

Analisis data dilakukan dengan menggunakan pengujian deskriptif komparatif yang bertujuan untuk mengetahui kinerja keuangan pada PT. Bank Negara Indonesia (Persero) Tbk. tahun 
Vol. 1, Juli 2021

2019-2020.

Analisis dalam penelitian ini menggunakan pendekatan kuantitatif yaitu mengklarifikasikan, menghitung, dan menganalisis data. Pada tahap ini, data diolah dan dimanfaatkan sedemikian rupa sehingga pada akhirnya berhasil menyimpulkan kebenarankebenaran yang dapat digunakan untuk menjawab permasalahan yang diajukan dalam penelitian.

Dalam penelitian ini akan dilakukan perhitungan terhadap rasio keuangan yang meliputi :

1. Rasio Likuiditas

a. Rasio lancar

$\mathrm{CR}=\frac{\text { Aktiva Lancar }}{\text { Hutang Lancar }} \times 100 \%$

b. Rasio cepat

$\mathrm{QR}=\frac{\text { Aktiva Lancar }- \text { Persediaan }}{\text { Hutang Lancar }} \times 100 \%$

2. Rasio Solvabilitas

a. Rasio Hutang terhadap aset

Debt Ratio $=\frac{\text { Total } \text { Hutang }}{\text { Total Aset }} \times 100 \%$

b. Rasio hutang terhadap ekuitas

DER $=\frac{\text { Total } \text { Hutang }}{\text { Ekuitas }} \times 100 \%$

3. Rasio Aktivitas

a. Rasio perputaran aktiva tetap 
Vol. 1, Juli 2021

Perputaran aktiva tetap $=\frac{\text { Penjualan }}{\text { Aktiva tetap }} \times 100 \%$

b. Rasio perputaran total aktiva

Rasio total aktiva $=\frac{\text { Penjualan }}{\text { Total Aktiva }} \times 100 \%$

4. Rasio Profitabilitas

a. Return On Assets Ratio

$$
\mathrm{ROA}=\frac{\text { Laba Bersih }}{\text { Total } \text { Aset }} \times 100 \%
$$

b. Return On Equity

$$
\mathrm{ROE}=\frac{\text { Laba Bersih }}{\text { Ekuitas }} \times 100 \%
$$

c. Gross Profit Margin

$$
\text { GPM }=\frac{\text { Laba } \text { Kotor }}{\text { Total Pendapatan }} \times 100 \%
$$

d. Net Profit Margin

$$
\text { NPM }=\frac{\text { Laba bersih seletah pajak }}{\text { Penjualan }} \times 100 \%
$$

\section{G. SISTEMATIKA PENULISAN}

1. Bab pertama merupakan isi dari pendahuluan yang menguatkan tentang latar belakang masalah, rumusan masalah, tujuan dan keguanaan penelitian.

2. Bab kedua merupakan isi dari tinjauan pustaka yang membahas tentang landasan teori dan kerangka fikir.

3. Bab ketiga merupakan isi dari metode penelitian yang menguraikan tentang lokasi dan waktu penelitian, jenis dan sumber data, teknik 
Jurnal Manajemen Keuangan

Vol. 1, Juli 2021

pengumpulan data, populasi dan sampel, definisi operasional variabel, analisis data dan sistematika penulisan.

4. Bab keempat merupakan isi dari pembahasan sejarah singkat perusahaan, hasil penelitian, dan menguraikan gambaran umum unit penelitian.

5. Bab kelima merupakan isi dari pembahasan isi dari penutup tentang kesimpulan dan saran. 
Jurnal Manajemen Keuangan

Vol. 1, Juli 2021

\section{DAFTAR PUSTAKA}

Fahmi, Irham, 2017. Analisis Laporan Keuangan (6 ed). Alfabeta. Bandung.

Kasmir, 2014. Analisis Laporan Keuangan, Jakarta: PT. Raja Grafindo Persada.

Munawir, S. 2014. Analisis Laporan Keuangan, Yogyakarta: LibertyYogyakarta.

Rodoni Ahmad, dan Herni Ali, 2014 Manajemen Keuangan Modern,Jakarta: Mitra wacana media.

Daga, $R$ (2017). STRATEGI MENINGKATKAN KEPUASAN NASABAH TABUNGAN PADA PT. BANK PERKREDITAN RAKYAT HASA MITRA CABANG MAKASSAR 